\title{
ジヒドロストレプトマイシンの内耳に及ぼす 影響に関する実験病理学的研究補遺
}

\author{
日本医科大学耳鼻咽喉科学教室（主任 大藤 敏三教授） \\ 内山 力 造 \\ Rikizō Uchiyama
}

\begin{abstract}
緒言
近来種々の抗生物質が相次いで発見されての恩恵を 受けること大なる反面思わざる副作用により不運な結 果を招く場合も起る事は周知の事実である。結核治療 剂として登場したストレプトマイシン（以下 SM) は その卓越せる力を発揮してすばらしい成果をあげたが 前庭機能障害を起すことが㞗々あつた。之の欠点を補 はんとして誘導されたジヒドロストレプトマイシン
\end{abstract}

（以下 DHSM）に期待がかけられたが之亦聴覚障害 を起す傾向が強く, 而もそれは一旦起つたが最後代償 可能な前庭障害と異なり殆んど回復することなく, 且 つ難聴の程度も一般に高度で遂に部に到るもの寸ら少 なくなかつた。即ち DHSMにより生命は救われても 犝という別の重荷を背負つて暗胆たる人生を送らねば ならぬことになり,重大な社会問題として注目された。 茲に於てストマイ難聴の本態究明と之による対策が緊 急事となり，多くの人々により探究されるに到つたが 末だ尚招解決の域に達していないのが現状である。

我が大藤教室に於ては眧和 27 年 11 月ストマイ難 聴の第 1 症(例 ${ }^{19)}$ を経験して以来逐次臨床報告 ${ }^{30)}$, 31) を してきた。昭和 29 年 10 月迄 SM による耳科的副作 用を認めた患者は合計 63 名 ${ }^{26)}$ であり，大部分 DHSM によるものであつたが,以後減少の傾向を示して扣り， 1959 1960 Year Book ${ }^{16)}$ V於て子 2 論文即ち E.G. Shambaugh の臨床報告及び Kanamycin によるもの があるに過ぎない。教室の 63 例に就き筋注群と髄腔 内注入群を比較するに後者では難聴の発現率及び程度 が高く大半乳幼児であることは特筆さるべきものとし て記載した。

SM 及びDHSMにより聴覚障害が起る際その初発侵 鋳部位はどこであるか。之に対しては臨床検查の方面 より有毛細胞障害と推定するもの多く，他方動物実験 よりは中枢変化ありとするもの, ラセン器の変性を 主とするものとが相半ばしている。即ち原発部位を中 权とするものとしてはStevenson, Alvord \& Correlli
(1947), Nielson \& Marsh $^{4)}$ (1948), Winston ${ }^{5}$ (1948, 1949), Dix, Hallpike \& Harrison ${ }^{8}$ (1949), Floberg, Hamberger \& Hydin $^{6)}$ (1949), Christensen, Hertz, Riskaer \& Vraa-Jensen ${ }^{9}(1950,1951)$, 等末稍とする ものとしては Glorig \& Fowler ${ }^{3)}$ (1947), Causśe (1948) Vanderboeghe (1949), $\operatorname{Berg}^{7}$ (1949) 等があり, 又 Rüedi は 1948 年中枢障害支記述したが 1951 年 ${ }^{10)}$, Mouse 飞於て未稍器管の障害であると認め, Hawkins は初め中枢系路の影響をも考えたが, 前庭機能検査及 び Cochlear Microphonic Response から末稍障害 ${ }^{12}$ であるとした。Mushett ${ }^{1}$ (1946) は前庭神経の中枢， 末稍共に侵されるとしている等不定なるも，中枢末稍 共に変化ありとして混合型主張するものが多くなつ た様である。

外国の最近の文献を2〜3あげると, Hawkins ${ }^{12}$ は猫 飞SM を注射して, 前庭機能Microphonic Response 及び生体固定を行つて, 前庭では水平半規管の Crista の有毛細胞の変性と固定の為めでない上皮の菱縮を，

又 Utricle Saccule に於ても同様の変化のみられたも のがあつた。蝸牛て於ては内有細胞は変性しているも のでも外有毛細胞は存在したが内有毛細胞の消失した 標本では外有毛細胞の変性があり, これは基礎廻転及 ひ2 2,3 廻転に多かつた。即ち内有毛細胞はSMに対し 特別に感受性であり, 又ラセン神経節の変性或は Stria vascularis の萎縮もあつた。之に対す討論で Guild は Crista の感覚細胞が或は血管の变化によるのではなか ろろかとし, Cristaの線毛感覚上皮の下に数個の毛細 管のある立方上皮の帯があり，前庭部に対する内リン パの一部はC ristaの感觉上皮に近いこの部でも分泌さ れるから下にある毛細管に対するSM の損賃が分泌機 能に変化を与兄るのではなかろろか。従つて vascular Injuryの見地からの研究を希旺すると述べていた。こ の内特に一般的に外有毛細胞から侵されるとの説に反 対の結果を出しているのが注目される。

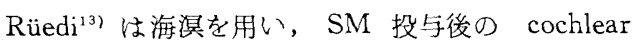




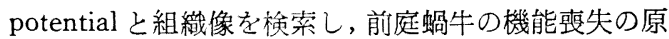
因を主として未梢感覚終末に於放変性によるとし， 更に Stria vascularis の病的変化と同様コルチ氏器と それに相応せる神経器官の激しい変性は基礎趈転に及 られたとし retrograde ascending Degeneration であろうとしたが之に同調する人るかなり多い。

Winston ${ }^{15}$ は DHSM 投与の猫の前庭中枢機構を以 下の方法で検索した。

(1) vital staining with trypanblue.

(2) histopathologic examination of brain sections stained with cresyl violet and phosphotun gstic acid.

最も著明な病変は小脳特に小葉と小結節のPurkinje cellsの内と周囲にみられた。この変化は核のPyknosis から細胞の完全消失に及んだ。 小脳の dentate and fastigial nuclei の細胞の structural aberrations も つた。然し Medulla の lateral vestibular (Deiter's) nucleus and the vental cochlear nuclei の細胞の損 傷は少なかつたという。

本邦でも之に関する動物実験は多く行われたが，大 沢 ${ }^{20}(1954)$ は海溟化 DHSM $400 \mathrm{mg} / \mathrm{kg}$ を 10 日間注 したところ 5 例全部に変化があらわれ, ラセン器の外 有毛細胞のミトコンドリアの消失を来し胞体腫脹, 内 部構造消失及び萎縮を認める飞到つた。守田 ${ }^{22}$ (1955) は同じく $200 \mathrm{mg} / \mathrm{kg}$ を 15 日間使用し，プライエル氏 反応は減退しなかつたが組織像は一般に基礎趈転の内 有毛細胞が膨化し, 外有毛細胞はすべて軽度に萎縮し ていた。その他実駼的に肝・腎障害を起したものに同 様注射しラセン器に軽度の变化を見たと報告されたが 詳細は不明である。肖藤等 ${ }^{21}$ (1955)はSM筋注DHSM, 複合 SM, Streptidine, Guanidin 等を大槽内に注入 し, 廻転後眼振消失は大量投与に扮いて Guanidin の みに見られず, Cochlear Response は SM, DHSM, で $4000 \mathrm{cps}$ の低下を見たが程度は小さく中枢性難㯖 の関与を推定した。久木元 ${ }^{23}$ (1955) は SM 又は DHSM を海淇に齚注して内耳の変化を調べ別に同様 の処置を行つた。此の实駼で内耳の病変は16 匹中半 数に現方我, 主に下方廻転に於て内有毛細胞住変性萎 縮更に崩填が認如られ，而もその程度は必ずしもSM 使用量とは平行せず亦中枢に於ても寒験動物の $1 / 3$ に 変化が見られたと拨告した。大和田等 ${ }^{28)}$ (1956)は DHSM 投与猫の組織所見上り少量注射時の歩行障害 は末稍迷路のみでなく小脳障害にも帰因していると推 論し, 佐藤 ${ }^{3+1}$ (1957) はSM 飞限らずへノポジ油,塩
酸キニーネ, サリチル酸ナトリウム等一般に鳃器毒素 と考えられている楽物を中毒量以下投与した場合の潜 在的な聴器中毒状態が音響性聴器外傷の一つの発現因 子となることに注意した。次いで発表された宇野 ${ }^{35}$ (1957), 高田 ${ }^{36)}$ (1957) の実験は夫々投与条件こそ違 へ，中枢と末稍の双方を観察するため生体固定に $5 \%$ ホルマリンを用い, 内耳の後固定に Wittmaack 氏液 を用いたのであるから内耳に関する限り浸漬固定と略 々同樣の変成を来すことになる。とすれば対照動物を 用いても必ずしも一定の成績を得ることは困難であ る。従つて上記の固定法ではラセン神経節細胞の所調 菱縮像の見られることは当然であつて之を以て末稍の 病変が中枢のそれより高度であるとの此の結論飞は肯 けない。一方志多 ${ }^{32)}$ (1957) は電気生理学的に検索し $200 \mathrm{mg} / \mathrm{kg}$ を 15 180 日間連日注射した海滇 28 例 中 3 例を除き 25 匹飞有毛細胞障害の起ることを認め, 先ず高音に対する。反応性が低下し, 侵襲の程度が強 くなるに従て低音域へと波及すると報告した。而して 之に用いた実験動物のうち 4 例飞生体固定を施し組織 学的にも検討し, 有毛細胞の変化として核の濃縮乃至 膨化から消失汇至る迄の変化原形質内に於㚈る空胞及 び顆粒状構造の発現, 細胞全体としての萎縮を認めた が, Hawkins ${ }^{12}$ (1952), Rüedi ${ }^{13)}$ (1952) の報告の如き 有毛細胞の消失は認められなかつたと言う。中村等 ${ }^{33}$ (1957) はSMによる聴器障害は内耳於ける血管帯 より始まり 2 次的にコルチ氏器の有毛細胞及び支柱細 胞に至る含水炭素を基礎とする代謝系の障害と中枢部 に於ける同様な障害及び内耳よりの 2 次的上向性変化 がその本態であることを発見し, 之等解诺呼财系障害 より連鎖的に蛋白, 燐, 脂肪等の代謝障害光と発展し て行くが，SM 投与によるこの様な聴器の解糖呼吸系 の障害は代謝のどの過程に於て障害を受けるかに就て は未だ允分解明されていないとした。只木 ${ }^{38)}$ (1958) は白衩ずみに $300 \mathrm{mg} / \mathrm{kg}$ を 35 50 日間連日筋注し 組織化学的に検索し, 聴覚中枢路の神経細胞のアルカ リ性 Ribonucleophosphatase 反応は一般に堌強する が，中毒が高度となると核小体汇於ける反応は低下或 は陰性化を示し, 且自己融解を思わせる像も增加する と報告した。中村 ${ }^{40)}$ (1959) は前述の志多, 只木を初 め数氏の業績を総括して電気生理学的に明かにされた 如く内耳に対する侵襲が第一の主因となり之に伴う上 行性の変化と別個に一次的に受ける中枢路の障害が難 聴の症状の固定化を来すと推論しているが, 更に検討 を要すべきことも多く今後とも種々の実験成績の累積 
(2091) - 175-

が望まれる。例党ば

1）DHSM 筋注（主に週 2 回）の場合の難聴発現 率は10\% 内外とされている。而も発現の過程が 不定で投与量, 投与期間によつて左有されぬこと が多い。一方動物実験では使用量的使用回数も人 体に比して遙に多いにしろ全例又は殆どの例に多 かれ少なかれ病変を見たという記载が多いのは何 故か。

2）喵道腔内に注入した方が筋注の場合より遙に多く 犝, 難聴を生ずる事実は中枢兄の侵警の大なるこ とを考觉てよいか。この比較実験はどうであるか。

3）Rüedi は動物に於て左右対称的飞侵されている 事を記载し, 臨床的にもこのような事実の多く起 ることは確められているが，其後この点にふれた 動物実験は見当らない。

以上の如き問題の一つを採上げても其の解決は容易 でない。私も今回 DHSM とよる内耳光の影響を実験 病理学的に検索し, 一応の成果を得るに到つたので此 処に報告し文献汇追加する次第である。

\section{実験}

\section{1. 実験動物}

体重 $400 \mathrm{~g}$ 以上の成熟海漠を用い鼓膜飞異常なく, プライエル氏反応のあることを確めた。

2. 実験方法

DHSM 0.5 0.6 g/kg を連日腹腔内に注射した。

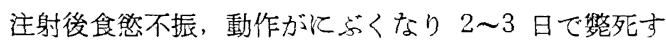
るもの多く，20回以上注射に耐光たものは僅か 7 匹だ けであつた。従つて注射回数は不規則で動物に番翼呼 四等の症状が現われ生存の見込なしと思われれば直に 生体固定を行つた。生体固定には Wittmack 氏液它 用い, 後固定, 脱灰, ツェロイヂン包埋等型の如く行 い,ヘマトキシリン・エオジン重染色を施して検索し た。

\section{3. 実験成績}

i) 注射 5 回以内のもの

201 号 (1回)；101,105,117,119,204,210 号 (2 回)；103，110,208号（3回）；102号 (4回)；114 号 (5 回)

組織学的所見:

内・外リンパ腔, 清澄

血管条, 前庭膜, 垷膜飞異常安垫的ない。

ラセン器, 外有毛細胞の核は金米嘘状に湛縮し, 胞体も亦細長くなり互に隙間岸つくり, 内有毛細 胞も生体固定特有の像を示し, ダイテルス以下の

\begin{tabular}{|c|c|c|c|c|c|}
\hline 動物番号 & $\begin{array}{l}\text { 実験当初 } \\
\text { 体 } \\
\text { (g) }\end{array}$ & $\begin{array}{l}\text { 生固 時 } \\
\text { 体 } \\
\text { (g) }\end{array}$ & $\begin{array}{l}\text { 注 } \\
\text { 射 } \\
\text { 回 } \\
\text { 数 }\end{array}$ & 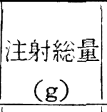 & $\begin{array}{l}\text { 注射終了後 } \\
\text { 固定迄の日 } \\
\text { 数 }\end{array}$ \\
\hline $\begin{array}{l}201 \\
101 \\
105 \\
117 \\
119\end{array}$ & $\begin{array}{l}415 \\
480 \\
610 \\
420 \\
445\end{array}$ & $\begin{array}{l}400 \\
453 \\
585 \\
398 \\
423\end{array}$ & $\begin{array}{l}1 \\
2 \\
2 \\
2 \\
2\end{array}$ & $\begin{array}{l}0.24 \\
0.5 \\
0.6 \\
0.5 \\
0.5\end{array}$ & $\begin{array}{c}\text { 即日 } \\
" \prime \\
" 1 \\
" 1 \\
" \prime\end{array}$ \\
\hline $\begin{array}{l}204 \\
210 \\
103 \\
110 \\
208\end{array}$ & $\begin{array}{l}576 \\
440 \\
570 \\
432 \\
510\end{array}$ & $\begin{array}{l}553 \\
409 \\
540 \\
405 \\
485\end{array}$ & $\begin{array}{l}2 \\
2 \\
3 \\
3 \\
3\end{array}$ & $\begin{array}{l}0.6 \\
0.5 \\
0.9 \\
0.7 \\
0.9\end{array}$ & $\begin{array}{l}\text { " } \\
\text { " } \\
\text { " } \\
\text { " }\end{array}$ \\
\hline $\begin{array}{l}102 \\
114 \\
113 \\
215 \\
121\end{array}$ & $\begin{array}{l}510 \\
573 \\
505 \\
464 \\
470\end{array}$ & $\begin{array}{l}474 \\
523 \\
467 \\
450 \\
447\end{array}$ & $\begin{array}{l}4 \\
5 \\
7 \\
7 \\
8\end{array}$ & $\begin{array}{l}1.0 \\
1.5 \\
1.75 \\
1.75 \\
2.0\end{array}$ & $\begin{array}{l}\text { " } \\
\text { " } \\
\text { " } \\
\text { " }\end{array}$ \\
\hline $\begin{array}{l}207 \\
213 \\
202 \\
116 \\
108\end{array}$ & $\begin{array}{l}465 \\
517 \\
520 \\
595 \\
615\end{array}$ & $\begin{array}{l}487 \\
492 \\
515 \\
553 \\
575\end{array}$ & $\begin{array}{l}11 \\
12 \\
15 \\
20 \\
21\end{array}$ & $\begin{array}{l}2.75 \\
3.0 \\
4.5 \\
6.0 \\
6.0\end{array}$ & $\begin{array}{c}\prime \prime \\
\prime \prime \\
\text { " } \\
\text { 8日 } \\
\text { 即日 }\end{array}$ \\
\hline $\begin{array}{l}203 \\
212 \\
115 \\
107 \\
205\end{array}$ & $\begin{array}{l}605 \\
480 \\
494 \\
585 \\
595\end{array}$ & $\begin{array}{l}570 \\
520 \\
535 \\
610 \\
570\end{array}$ & $\begin{array}{l}21 \\
21 \\
23 \\
25 \\
25\end{array}$ & $\begin{array}{l}4.35 \\
5.25 \\
5.75 \\
7.5 \\
9.0\end{array}$ & $\begin{array}{c}7 \text { 日 } \\
5 \text { 日 } \\
3 \text { 日 } \\
7 \text { 日 } \\
\text { 即日 }\end{array}$ \\
\hline
\end{tabular}

支持細胞にも变化を見ない。トンネル線維は明膫 である。

ラセン神経節細胞及び前庭・半規管にも特別の 所見を認めなかつた。

ii) 注射 7 15 回のもの

113,215号（7回）；121号（8回）；207号(11回）； 213号 (12回)；202号（15回）

組織学的所見:

内・外リンプ腔, 清澄

血管条, 前庭膜, 蓋膜飞変化を認めない。

ラセン器, 215 号両側, 121 号左, 207 号右の第 1 2迴転に於ては外有毛細胞の核は旅縮せず正円 形で淡染し,胞体も短縮し,稍々太くなつている。 内有毛細胞传著変はないが，その支持細胞は膨化 し, ヘンゼン, クラウデュース細胞は軽度に萎縮 して境界不明暸となつている。而して第 2 3 迴 転以上では変化を認めない。

213 号右の第 1 逼転の有毛細胞に変化はないか クラウデュース細胞㜆化し空胞を形成している。

113 号両側, 121 号右, 207 号左, 213 号左, 202 号両側には殆ど变化を認的なかつた。

ラセン神経節細胞及び前庭・半規管には変化を 見ない。

iii) 注射 20 回以上の!の 
116 号 (20回)；108,203,212 号 (21回)；115号 (23回)；107,205 号 (25回).

組織学的所見:

内・外リンパ腔, 清澄

血管条，前庭膜，蓋膜飞変化を認めない。

ラセン器, 116 号左は下方廻枟より第 3 趈転前 半に至る迄外有毛細胞消失し指節突起の一部のみ 認められる。内有毛細胞には著変を見ない。ダイテ ルス,ヘンゼ:細胞は軽度に萎縮し境界不明暸と なつているし，亦トンネル線維は消失している。

115 号両側, 212 号右, 107 号右飞於ては下方 廻転より第 $2 \sim 3$ 廻転迄外有毛細胞の核の円形淡 染又は一部消失が所々不規則飞認められる。しか し内有毛細胞には著変なく, ダイテルス, ヘンゼ ン細胞は一部萎縮し配列が乱れている。トンネル 線維は消失している。

116 号右, 108 号左, 212 号左の下方廻転飞於 ては有毛細胞の核が円形焱染するもの多く，支持 細胞の境界る稍々不明瞭となつているがトンネル 線維は認められる。203,205 号は両側とも著変を 認めなかつた。

ラセン神経節細胞, 一般汇著変なく, 116号左, 212 号右, 108 号左の下方迴転に於てニッスル小 体稍々不明瞭となつているが，䓺縮等は認められ ない。

前庭・半規管, 前庭神経節細胞はいずれも変化 を認めない。

\section{総括並に考按}

上述の如く DHSM を比較的大量注射したため動 物は食恣不振動作緩慢となり2〜3 日で擎死するもの が多かつた。而して注射 5 回以内で生体固定を行つた ものの内耳には殆ど所見なく, 注射 7 15 回の 6 例 12 耳中 4 例 5 耳の下方迴転に於てラセン器外有毛細胞の 核は円形に淡染し, 胞体も短縮して稍々太くなつてい る。内有毛細胞には藷変ないが, ヘンゼン, クラウデ ニース細胞は軽度飞溇縮するもの多く又空胞形成も一 例飞認められた。蝸牛の他の部分及び前庭・半規管に は異常を認めなかつた。

注射 20 回以上の8のでは 7 例 14 耳中 4 例 5 耳に 高度の， 3 例 3 耳飞柽度の变化を茪た。即ち第 1 趈枟 より第 2 3 迴転に至るラセン器外有毛細胞の消失或 はその核の変形又は消失が見られたが，内有毛細胞に は著変学㴓めなかつた。ダィテルス,ヘンゼン細胞は 菱縮し配列が乱れているところが多く、トンネル線維
は消失している。又変化の軽度のるのでは下方廻転に 於て有毛細胞の核が円形飞焱染するすの多く, 支持細 胞の境界も稍々不明瞭となつているがトンネル線維は 認められる。ラセン神経節細胞は一般とは著変はない が，一部のものの下方迴転でニッスル小体が稍々不明 膫となつているのが見受けられた。しかし萎縮像は認 められなかつた。前庭・半規管には変化を見ない。以 上の成績の如く海滇飞 DHSM を 0.5 0.6 g $/ \mathrm{kg}$ 連日 注射する時は全身障害が強く起り, 実験の中途で警死 するもの多く所期の量を注射出来たものは少なかつ た。

而して 10 回前後の注射を行い得た 6 例 12 耳とあ つては其中 4 例 5 耳の下方迴転に於て外有毛細胞の核 が金米糖状飞濃縮せず, 円形飞淡染し, 胞体子短縮し て稍々太くなつていたことはW氏固定液に対する正常 組織の反応像と解し得なかつた。即ち活力が減退して いたと見做して䛊りないであろう。

注射 20 回以上のものでは 7 例 14 耳中 4 例 5 耳の 第 1 迴転より第 2 3 迴転に至る外有毛細胞の消失乃 至はその核の変形又は消失が見られたが, 内有毛細胞 には著变を認めなかつた。Hawkins ${ }^{22}$ (1952) 愔隦 性外傷や薬剤とよる中毒の時と違つてDHSM では内 有毛細胞の選択的障害像を示すと云い，久木元 ${ }^{23}$ も之 飞同調しているが, 私の成績では外有毛細胞飞活力の 低下又は核及び胞体の形驡的変化を確認しているが此 の時期では未だ内有毛細胞には明らかな変化は起つて いなかつた。支持細胞の变化はこの場合全般的に見て 程度は軽いものであるから, 二次的に起つたものと推 定して差支觉ないであるろ。

而して有毛細胞の消失という可成りの変化飞子拘ら ずラセン神経節細胞には未だ大した変化が見られなか つたことは動物の生存日数が 1 力月以内とい万短期間 であつた為めであろう。従つて retrograde ascending Degeneration なるものは本実験では明確には証明さ れなかつた。

次に臨床的に聴力障害の常に両側性であることが Gloring $^{11)}$ (1951) 飞より強調され，両側同時に同じ速 度で悪化するという。立木 ${ }^{24}$ ) (1955) も 36 例の検査 の結果筋注を行う限り殆ど左右対称の聴力像を呈する と報じている。しかし非対称性の存在を認める $\mathrm{Höh}^{17}$ (1952), 切替 (1953), 河村等 ${ }^{199}$ (1954), 市川 ${ }^{25}$ (1955) 等もある。一方動物実験で Rüedi ${ }^{13)}$ (1952) は刘称的 そ侵されているのを報じているが，使用薬戍はSMで 総量 $5.5 \mathrm{~g}$ を 1 カ月に亘り注射した唯の1例の所見で 
あるから真偽の程はわからない。爾来多くの実験が絽 り返されたにも拘らず此の点にふれた記載が見当らな い。前述の電気生理学的飞検索した志多 ${ }^{32}$ (1957) の 実験に於ても技術的困難はあるかもしれないが，若し 左右の蝸牛電位を夫々検出し得たとしたら更に信頼す ると足る業績となつたであろう。私の実験例では10回 前後の注射群 6 例 12 耳中 4 例 5 耳飞変化があり, 其 中両側ともに変化のあつたものは 1 例だけ, 亦 20 回 以上の注射例では 7 例 14 耳中, 両側同様の変化を起 したもの 1 例, 左右不同ながらも両側変化のあつたも の 2 例, 一側の及 2 例, 両側とも変化ないるの 2 例で 㐫つた。即ち左右の対称性については此の成績からは 何とも言光ない結果となつた。

さてストマイ難聴の発現率恃週 2 回筋注の場合 $10 \%$ 内外とていされる。勿論この発現には投与量, 投与期 間，結核等の原病に上る全身障害 (肝・腎機能障害)

等も関連してくるが，それのみでは説明のつか奴こと が多く，DHSM に対する感受性の個人差を認めるげ ならぬ。立木 ${ }^{24)}$ (1955) も之を強調し，更に先天的素 因る考慮に入れるべきだとしている。周知の如く抗生 剤は一般の薬物に比し毒性が極めて低い。従つて薬理 学的の面からの投与量, 投与期間の比較は困難であ る。依つて動物使用した場合子常洞じ結果を得る とは限らない。この点にふれ個体差を認めているのは 前述の久木元 ${ }^{23}$ だけであり，他はすべて実験全例㲹或 は大部分 (80 90\%) 飞変化を証明している。之は却 つて招かしなもので考克ようによつては Rüedi ${ }^{13}$ の如 き唯 1 例の所見即ち症例報告の加きものの累積が真実

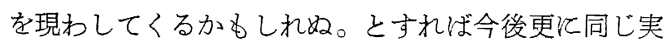
験を繰返すことも意味があるし，究極的汸ストマイ

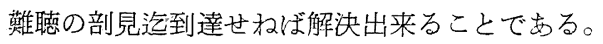

私は一応 DHSMの内耳に及に゙す影響を実験的に検 討したが，中枢飞対する影㗽も決して除外し得ない。 唯中枢と内耳を共に検索することは前記の宇野 ${ }^{35)}$, 高 $\mathbb{1}^{36}{ }^{36}$ の実験の如く無理があるので未稍の状態のみの祫 索に止つたのである。文献に上れば病理組織学的に中 枢江於て蝸牛神経背側核, 同腹側核, 台形体, 外側毛 带核, 下丘, 内側滕状体及び皮質領域等にも変性症状 定検出しているし，亦組織化学的飞蝸牛神経中枢路飞 於ける神経細胞の代謝失調を確認したと称するもの

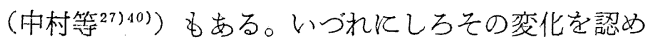
たと称する部位が非常に広笧囲である点が特色で，こ の複雑性は臨床的にストマイ難聴の発生が個体差によ つて必ずしも同一傾向に出ないという褰付けになると
推論しているが，亦逆に考兄れば検索方法に怙とし穴 があるのではないかとも想像される。

尚招ストマイの構造及び副作用発現機序関し, そ の構造式は1945年Peck飞より Streptidine, Streptose, N-Methylglucosamine の 3 部より成ることが知られ， SM の抗菌作用並びと毒作用は主として Streptidine によると考兄られるが, Hennebertは核蛋白の障害に よるとし，Fitzgerald 等は SM が結核菌の核酸代謝 飞必要な適応酵素の生成を抑制すると起因するとし た。志多等 ${ }^{39}$ (1959) は DHSM 飞特有な難聴発現性 は恐らく Dihydrostreptobiosamine 中の N-MethylL-Glucosamine を除いた構成分である Dihydrostreptose 飞負うものと推論した。SM と DHSM との構 造の差はStreptobiosamine と Dihydrostreptobiosam. ineでありそそれは Streptose が Dihydrostreptose と なる点以外にはなく,この観点からDHSM への転換使 用によるストマイ難聴の発生増加を鮡めると DHSM の難聴発現因子を Dihydrostreptose とする推論は一 首確実性を增す様隹われると述へている。ともあれ ストマイ難聴には未解決の問題が尚抏潜んでいる。

\section{結論}

DHSM を海溟に連日注射して内耳に及ぼす影㗽を 組織学的に検索し，次の如き成果を得た。

1.10回前後の注射を行つた約半数仿於て下方迴転 の外有毛細胞の核が円形に淡染し, 胞体子短縮して稍 々太くなつていつたことはこの細胞の活力の減退を思 わせる。

2. 20 回以上のものでは約 $1 / 3$ 亿高度の一部軽度 の変化を見た。即ち第 1 迴転上りも第 $2 \sim 3$ 畐転任至 る外有毛細胞の消失或はその核の変形又は消失が見ら れたが，内有毛細胞には著変を認め得なかつた。

3. 支持細胞の変化は一般には顕著でない。亦ラセ ン神経節細胞の変化は少く， Retrograde ascending Degeneration は証明されなかつた。

4. 前庭・半規管には変化を認めなかつた。

5. DHSM による内耳への侵襲部位としての初発 変化がラセン器外有毛細胞に於て証明された。

終りに臨み終帟御指導を賜はつた恩師大藤教授と実験に際 して絶えず御教示と御指導を晹はつた野本翡師に满腔の感謝 を捧行る。又研究中種々御配虑を賜はつた日本医科大学耳鼻 咽喉科教室員各位と本研究に御協力御助力戴いた 河村博士に 篤く感謝する次第である。

\section{参 考 文 献}

1) Mushett, C.W. and Martland, H.S. : Pathologic 
Changesresulting from the Administration of SM; Arch. Path., 42,(12), 619 (1946)

2) Stevenson, L.D., Alvord, E.C. and Correll, J.W. : Degeneration and Necrosis of Neurones in Eighth Cranial Nuclei caused by SM; Proc. Soc. Exper. Biol. \& Med., 65, 86, (1947).

3) Glorig, A and Fowler, E.P. : Tests for Labyrinth Function following SM Therapy; Annalsof Otos Rhino. \& Laryng., 56, (6), 379 (1947)

4) Nielson, I.M. and Marsh, C.: SM Therapy; The pathological Basis of vestibular Disturbance. Bull Los Angeles Neurol. Soc., 13, 99 (1948)

5) Winston, J., Lewey, F.H., Parentean, A.,Marden, P.A. and Cramer, F.B. : An experimental Study of the toxic Effects of SM on the vestibular Apparatus of the Cat; Annals of Oto. Rhino. \& Laryng., 57, (9), 738 (1948)

6) Floberg, L.E., Hambergee, C.A. and Hydin, H. : In hibition of Nucleic Acid Production in ve stibular Nerve Cellsby SM.; Acta Oto-laryng., Suppl. 75, 36 (1949)

7) Berg, K.: The toxic Effect of SM on the Eighth Cranial Nerve ; Annals of Oto. Rhino. \& Laryng., 58, (6), 448 (1949)

8) Dix, M.R., Hallpike, C.S. and Harrison, M.S. : Some Observations upon the otological Effects of SM Intoxication; Brain, 72, (6), 241 (1949)

9) Christensen, F., Hertz, H., Riskaer, N. and Vraa-Jensen G., : Experiments on Neurotoxic Effect of SM ; Acta Oto-laryng., Suppl. 95, 165 (1951)

10) Rüedi,L. : Some animal experimental Findings on the Functions of the inner Ear; Annals of Oto. Rhino. \& Laryng., 60, (4), 993 (1951)

11) Gloring, A. : The Effect of Dihydrostreptomycin hydrochloride and sulfate on the auditory Mechanism; Annals of Oto. Rhino. \& Laryng., 60, (6), 327 (1951)

12) Hawkins, J.E., Rahway, N.J. and Lurie, M.H. : The Oto-toxicity of Streptomycin; Annals of Oto. Rhino. \& Laryng ; 61, (9), 789 (1952)

13) Rüedi, L, Furren, E., Luthy, F., Nager, G. and Tschirren: Further Observations concrening the toxic Effects of Streptomycin and Quinine on the auditory Organ of Guinea Pigs; Laryngoscope, 62, (4), 333 (1952)

14) Winston, J., Lewey, F.H., Parenteau, A., Marden P.A. and Cramer, F.B.: Further experimental Studies of the toxic Effects of SM on the central vestibular Apparatus of Cat; Annals of Oto. Rhino. \& Laryng., 58, (12), 988 (1949)

15) Winston, J., Lewey, F.H, Parenteau, A., Spitz, E. and Marden, P.A. : Toxic Effect of Dihydrostreptomycin of the Cat; Annals of Oto. Rhino. \& Laryng., 62, (3) 121 (1953)

16) Lindsay, J.R., Lierie, D.M. and Huffman, W.C. : The Year Book of the Ear; Nose \& Throat., (1959-1960 Year Book Series), 72 (1960)

17） Höh : Zft. L.R.O., 31，223 (1952), (支献より引 用)
18）切替一郎：ストレプトマイシンと 聴器障害；診療の実 際 4, (4), 226 (1953)

19）内山力造, 河村進市：ストレプトマイシンによる副作 用特に聴覚障害に就て; 耳喉，26，(2)，57 (1954)

20）大沢正人：聴器ミトコンドリアに関する 実験的研究, 第 7 報ストレプトマイシンの障害；白耳, 57 , (3), 271, (1954)

21）斎藤章二, 德永友喜子, 大和田健次郎，中村よし子： ストマイと聴器障害についての実験的研究; 日耳, 58, (6), 666 (1955)

22) 守田 晃：ストレプトマイシンによる 聴器障害につい ての実験的研究; 日耳, 58, (臨時)，228 (1955)

23）久木元正延：ストレプトマイシンの聴器に 及ぼす影临 についての実験的研究 (1 3 編) ; 耳臨, 48, (8), 573 . (1955)

24）立木 孝：ストレプトマイシンによる 恥覚障害につい て; 日耳, 58, (11), 1228, (1955)

25）市川則雄：ストマイ使用結核患者の聴力検査成績；耳 喉, 27，(11)，602，(1955）

26）大藤敬三, 河村進市, 内山力造 : ストマイによる副作 用, 特に最近の結核性髄膜炎後難聴を中心とした考察； 医事新報, 1617，1854（1955）

27）中村文雄, 水越治：聴中枢化学より見たストレプトマ イシン難聴; 耳喉, 28, (2), 69 (1956)

28）大和田健次郎, 中村よし子, 斎藤章二, 德永友喜子： ストレプトマイシンによる聴器障害 についての実験的 研究 (第 2 報); 日耳, 59, (2)，242(1956)

29）川口き收：ストレプトマイシンによる聴器障害につい ての臨床的研究; 耳聴, 49, (8), 553 (1956)

30）河村進市,川島恒三：ストマイによる副作用続報, 特に SM 過敏症を中心と乙て; 耳喉, 28,(10), 651(1956)

31）大藤敏三，河村進市：ストレプトマイシン難聴；耳鼻 咽喉科最近の進歩, 229, (1956)

32）志多 享: Dihydrostreptomycin の蝸午障害並びに Chondroitin sulfate の該障害に対する予防効果に関 する実験的研究；日耳，60，(2)，164（1957）

33）中村文雄, 小西輝三, 水越治：ストレプトマイン難聴 の臨牀と病理；耳と臨床，3，(4)，227 (1957)

34) 佐藤武男 : 聴器毒投与動物の 音響受傷性に関する実験 的研究; 日耳, $60,(5), 479,1957$

35）宇野昭二：ジヒドロストレプトマイシンの 聴器中毒に 関する実験病理組織学的研究); 耳臨, 50，(8)，785 (1957)

36) 高田 渙：ジヒドロストレプトマイシンとストレプト マイシンの内耳神経に対する侵襲態度についての実験 的研究; 耳臨, 50, (9), 712 (1957)

37）牧瀬昭広：ストレプトマイシン難聴に関する 実験的研 究, 前編 $\left(V . B_{1}\right.$ の Dihydrostreptomycin 難聴に対 する予防効果に闒する臨床的研究)；耳鼻之臨床，4， (4), 309 (1958)

38）只木信和：聴覚中枢路の Ribonucleophosphatase に 関する研究; 耳臨, 51, (7), 626 (1958)

39）志多享, 椹田秀雄, 小西輝三: Dihydrostreptomycin の難德発現性とその化学構造との関聯性について; 耳 喉, 31, (2), 141(1959)

40）中村文雄：ストレプトマイシン難恥；第 15 回日本医 学会誌, 277 (1959)

41）佐藤重一：ストレプトマイシンによる聴器障害；第 15 回日本医学会会誌, 278 (1959) 
内山論交附図 (1)
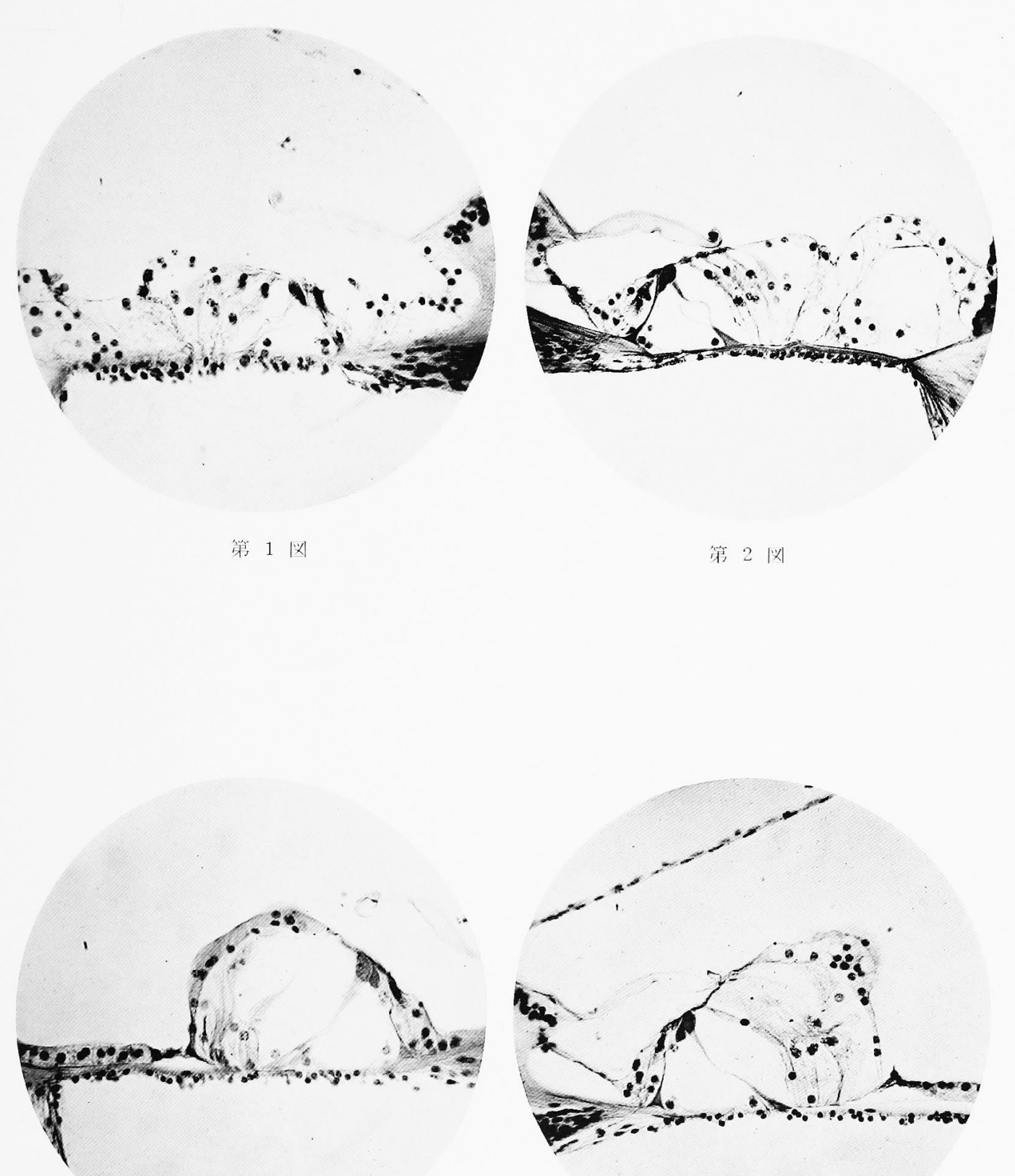
内山論文附図 (2)
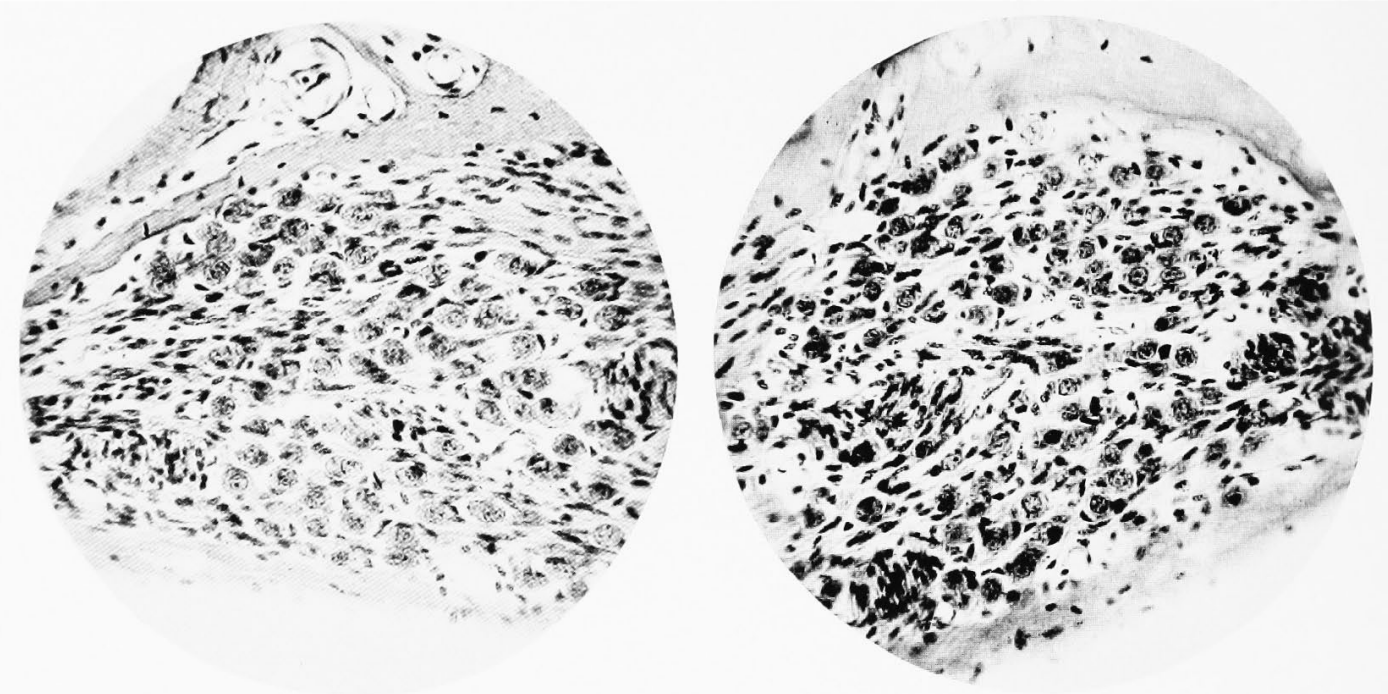


$$
(2095)-179-
$$

\section{附図説明}

第 1 図, 121 号左。第 1 迴転後半。注射 8 回。外有毛細胞 の核は正円形に淡染, 胞体も短蓿し, 稍々太くなつている。 ヘンゼン, クラウデニース細胞は軽度に菱縮して境界不明暸。 第 2 図, 213 号右。第 1 迴転後半。注射 12 回。有毛細胞 に変化はないが，クラウデニース細胞膨化し空胞形成。

第 3 図, 116 号左。第 3 迴転前半。注射 20 回外有毛細胞 はすへて消失しているが, 内有毛細胞には著変ない。ダイテ ルス,ヘンゼン細胞萎縮。トンネル線維消失。
第 4 図, 212 号右。第 3 迴転後半。注射 21 回。第2 3列 の外有毛細胞の核が消失し, 胞体は膨化し境界不明。内有毛 細胞は全く異常を認めない。

第 5 図, 203 号右。第 1 迴転後半。注射 21 回ラセン神経 節細胞異常を認胁ない。

第 6 図, 108 号左。第 1 迴転前半。注射 21 回。ラセン神 経節細胞, ニッスル小体幾分不明瞭となるも萎縮像は全く見 られない。 